\title{
Current challenges of globalization in the automotive industry in European countries
}

\author{
Vladimír Hojdik ${ }^{1, *}$ \\ ${ }^{1}$ University of Economics in Bratislava, Faculty of Business Management, Department of Business \\ Economy, 85235 Bratislava, Slovakia
}

\begin{abstract}
.
Research background: Research in this paper is based on analysis of data and documents published by official institutions and relevant studies and papers.

Purpose of the article: This paper assesses how the pandemic situation influenced automotive sector in countries of Europe. It evaluates differences between European countries, in terms of automotive industry operation after COVID-19 crisis. It also outlines global trends and challenges for future industry development.

Methods: In the research, we use mainly general methods, especially analysis, synthesis and comparison. Among the specific methods, we use statistical methods to obtain, process, explain and interpret data.

Findings \& Value added: In the findings we present the impact of COVID-19 on automotive industry in European countries. In the end, we present thoughts on globalization challenges for automotive industry, and possible ways for its future development.
\end{abstract}

Keywords: automotive industry performance, industry development, European countries, global challenges

JEL Classification: $L 16, L 62, O 30$

\section{Introduction}

Global economic system is experiencing difficult times nowadays, especially because of negative consequences of COVID-19 pandemic situation. A similar statement can be applied to the economies of European countries. Among the most affected sectors it can be ranked automotive industry, which is one of the most dominant contributors to European GDP. Automotive industry represents very important sector of European economy. Its importance is even more visible in Slovakia, where automotive remains a key aspect of economic performance.

This sector as a whole has some specifics. It includes not only producers, but also suppliers and partially resellers (resellers officially belong to sector of commerce/retail in some countries). Production of the final product (automobile) is a complex process, wide

\footnotetext{
${ }^{*}$ Corresponding author: vladimir.hojdik@euba.sk
} 
range of components is necessary and automotive industry is thus closely connected with the other sectors of the economy. Businesses operating in this sector are cooperating together and create complex supply chains, which fosters the importance of automotive even more [1].

The industry has a relevant impact on economy and technological development. Humprey and Memedovic state that the automotive sector has global character and represents a capital-intensive industry characterized by vertical integration. Automotive industry also contributed to innovation development and fundamental industrial production changes [2].

The ecosystem of automotive industry creates a workplace for 14,6 million Europeans, what represents 6,7 percent of total European Union employment. Automotive industry accounts for 8,5 percent of European manufacturing jobs with 2,7 million people working on the manufacturing of vehicles across 226 factories in the European Union [3].

By the time, automotive sector became the pillar of the European economy. However, current situation is an unprecedented complication for this sector. Negative consequences of COVID-19 crisis are clearly visible also on the operation of automotive industry. Thus, it is important to assess the competitiveness within the industry and find new policies in order to support the recovery of the sector. This paper focuses on analysis of key automotive industry data in context of current situation and discusses new global challenges for the sector.

\section{Methods}

With the objective to the aim of the paper, we wanted to use the most appropriate methods. Research of the paper is based on thorough analysis of existing databases provided by specialized institutions. According to the character of the research, especially general research methods were used. In the process of the research we used mainly analysis, synthesis, comparison and generalization. Among the specific methods, we used appropriate methods to obtain, process, explain and interpret data.

General methods - analysis, comparison, synthesis, were predominantly used to define the position of automotive industry in Europe. This part of the work describes the role of automotive sector in Europe and it was processed with use of official documents published by professional institutions and relevant scientific papers. Following part of the paper focuses on current situation and it is based on analysis of coronavirus impact on automotive industry performance. In the final part of the paper, we compare and integrate the collected data and we formulate general considerations about the automotive industry future from global perspective.

\section{Results and discussion}

\subsection{Position of automotive industry in European Union countries}

Automotive industry has strong position in economy of European Union, what is confirmed by key statistic data. As we listed above, manufacturing of motor vehicles employed 2,7 million people, what equals 8,5 percent of total manufacturing employment. In terms of production, in 2019 there were 18,5 million of vehicles produced in European Union, what is 20 percent of global motor vehicle production. Automotive industry has strong impact on trade, too. Total motor vehicle exports reached the level of 136 billion EUR, total value of imports was 62 billion EUR - automotive industry thus accounted for trade surplus of 74 billion EUR. Moreover, automotive strongly helps to build innovation ecosystem. Total 
amount of automotive research and development investments was 61 billion EUR in year 2018 [3].

\subsubsection{Production}

Production of cars in Europe has long-time tradition, and Europe is among the strongest automotive industry regions together with China and Northern America. However, outbreak of coronavirus pandemic also translated into lower production in European countries. Following table informs about car production in European countries in 2018 [3].

Table 1. Data about automotive industry production for EU countries in 2018

\begin{tabular}{|l|c|c|}
\hline & Number of passenger cars produced & Number of total cars produced \\
\hline Austria & 158400 & 176801 \\
\hline Belgium & 247020 & 285454 \\
\hline Czech Republic & 1427563 & 1428620 \\
\hline Finland & 114161 & 114287 \\
\hline France & 1675198 & 2303699 \\
\hline Germany & 4661328 & 5164528 \\
\hline Hungary & 498158 & 498158 \\
\hline Italy & 542007 & 879724 \\
\hline Lithuania & - & 56 \\
\hline Netherlands & 176113 & 258339 \\
\hline Poland & 434700 & 642502 \\
\hline Portugal & 282142 & 369988 \\
\hline Romania & 490412 & 1069442 \\
\hline Slovakia & 1069442 & 199102 \\
\hline Slovenia & 199102 & 2915432 \\
\hline Spain & 2248019 & 333309 \\
\hline Sweden & 285709 & 1377982 \\
\hline $\begin{array}{l}\text { United } \\
\text { Kingdom }\end{array}$ & 1303135 & 18507834 \\
\hline TOTAL & 15812609 & 12012 \\
\hline
\end{tabular}

Automotive industry production data for the year 2018 are presented in Table 1 [3]. From the data it is obvious, that production of passenger cars has a dominant position. In 2018, all European countries manufactured almost 16 million of passenger cars. The largest European producer is Germany with more than 4,6 million vehicles. Next in the rankings is placed Spain with 2,2 million passenger cars. France, United Kingdom, Czech Republic and even Slovakia all exceeded the level of 1 million cars. This fact is notable, especially when we consider the size of the countries: population of France and United Kingdom is roughly 67 million, Slovakia has 5,5 million inhabitants and Czech Republic approximately twice as much. Despite the big difference in population numbers, all countries are on similar level by car production. This is the proof that Slovakia and Czech Republic are much more dependant on automotive sector than France or UK. Other countries do not come even close to level of 1 million passenger cars and Lithuania, interestingly, does not manufacture passenger cars at all. 


\subsubsection{Employment}

Automotive industry significantly supports employment, as it provides huge number of working places and helps to create new jobs. Table below shows what is the exact number of people employed in sector of automotive industry. It also informs about the relationship between automotive industry and whole manufacturing sector.

Table 2. Data about automotive industry employment for EU countries in 2018

\begin{tabular}{|c|c|c|}
\hline & People employed & $\begin{array}{c}\text { Share of direct automotive employment on total } \\
\text { manufacturing }\end{array}$ \\
\hline Austria & 39569 & 5,9 \\
\hline Belgium & 28768 & 5,9 \\
\hline Bulgaria & 23777 & 4,3 \\
\hline Croatia & 2919 & 1,1 \\
\hline Cyprus & 168 & 0,5 \\
\hline Czech Republic & 181415 & 13,7 \\
\hline Denmark & 4317 & 1,4 \\
\hline Estonia & 2880 & 2,6 \\
\hline Finland & 10199 & 3,0 \\
\hline France & 229422 & 7,4 \\
\hline Germany & 882046 & 11,8 \\
\hline Greece & 1737 & 0,5 \\
\hline Hungary & 101865 & 12,9 \\
\hline Ireland & 3000 & 1,4 \\
\hline Italy & 176303 & 4,6 \\
\hline Latvia & 2317 & 1,9 \\
\hline Lithuania & 6163 & 2,8 \\
\hline Netherlands & 25204 & 3,5 \\
\hline Poland & 213708 & 7,5 \\
\hline Portugal & 42358 & 5,8 \\
\hline Romania & 190848 & 15,8 \\
\hline Slovakia & 81273 & 15,8 \\
\hline Slovenia & 15887 & 7,4 \\
\hline Spain & 162634 & 8,0 \\
\hline Sweden & 90473 & 14,0 \\
\hline United Kingdom & 166228 & 6,4 \\
\hline TOTAL & 2685478 & - \\
\hline
\end{tabular}


Table 2 indicates, what is the automotive industry share on total manufacturing employment [3]. The amount of jobs directly created by European automotive industry is almost 2,7 million, however, we cannot forget other jobs which are created indirectly.

The differences between countries are significant: in Latvia only 2 percent of manufacturing jobs belong to automotive industry, while in Slovakia and Romania this rate is almost 16 percent. Czech Republic, Hungary or Sweden report similar results, but it is necessary to look behind the numbers.

Slovakia, Romania, Czech Republic and Hungary are countries of former East Block, and thus the manufacturing tradition has long-term character. Automotive investments in these countries were directed with aim to foster production of parts and cars, but not research and development. Continuous neglect of R\&D investments and strong reliance on production process leads to increased risks caused by possible production interruptions, what exactly happened when COVID-19 crisis broke out. For example, Germany as the biggest European producer of cars is big investor to research and development as well. For all countries, it is important to find the balance between production and $\mathrm{R} \& \mathrm{D}$, in order to minimize potential job losses in unpredictable situations.

\subsubsection{Innovation potential}

In comparison to other sectors, automotive industry has superior position in terms of innovation expenditures. Table below shows differences between expenditures to research and development in various sectors of economy. Data in the table prove that automotive industry is the biggest investor in research and development in European Union, being responsible for 29 percent of total R\&D spending [3].

Table 3. Data about innovation within European automotive industry in 2018

\begin{tabular}{|l|c|c|}
\hline & $\begin{array}{c}\text { R\&D amount in } \\
\text { billions }\end{array}$ & $\begin{array}{l}\text { Share of R\&D in EU } \\
\text { countries }\end{array}$ \\
\hline Automobiles and parts & 60,9 & 29 \\
\hline Pharmaceuticals and biotechnology & 39,9 & 8 \\
\hline Technology hardware and equipment & 15,9 & 5 \\
\hline Electronic and electrical equipment & 10,9 & 5 \\
\hline Software and computer services & 10,5 & 5 \\
\hline Industrial engineering & 9,9 & 4 \\
\hline Banks & 9,3 & 3 \\
\hline Aerospace and defence & 9,3 & 3 \\
\hline Health care equipment and services & 5,5 & 15 \\
\hline Chemicals & 5,2 & 4 \\
\hline Other sectors & & 5 \\
\hline
\end{tabular}

\subsection{The impact of COVID-19 crisis on European automotive industry}

It is now generally accepted that the emergence of coronavirus has triggered an unprecedented global crisis [4]. The effect of COVID-19 was apparent even on European automotive industry. Most manufacturers were forced to stop their production and 
development processes for several weeks or months. Even though the exact impact of coronavirus for full year 2020 remains unknown, data obtained at the peak of the crisis show how automotive sector was damaged. Following table contains data about the coronavirus impact on employment and production in some of European countries [3].

Table 4. The impact of COVID on automotive industry in selected EU countries

\begin{tabular}{|l|c|c|}
\hline & Number of employees affected & $\begin{array}{c}\text { Estimated production loss (number } \\
\text { of cars) }\end{array}$ \\
\hline Austria & 14300 & 26480 \\
\hline Belgium & 30000 & 33360 \\
\hline Croatia & 700 & 155060 \\
\hline Czech Republic & 45000 & 11600 \\
\hline Finland & 4500 & 278425 \\
\hline France & 90000 & 616590 \\
\hline Germany & 568000 & 51550 \\
\hline Hungary & 30000 & 157933 \\
\hline Italy & 69000 & 30819 \\
\hline Netherlands & 13500 & 101960 \\
\hline Poland & 17300 & 41520 \\
\hline Portugal & 20000 & 68670 \\
\hline Romania & 20000 & 114630 \\
\hline Slovakia & 20000 & 19400 \\
\hline Slovenia & 2900 & 452155 \\
\hline Spain & 60000 & 23464 \\
\hline Sweden & 67000 & 2446344 \\
\hline United Kingdom & 65500 & \\
\hline TOTAL & 139000 & - \\
\hline
\end{tabular}

Table 4 contains data about the crisis impact on the production and jobs [3]. Among the most affected countries there are Germany, Spain, France, UK, but also Slovakia, where we can see sharp decline in production of vehicles. Manufacturing processes in these countries had to face serious complications, as wide range of factories were shut down during the coronavirus spread. Interruptions of production also translated into labour market and employment as more than 1,1 million workplaces were directly affected. In terms of Slovakia, the crisis affected approximately 20000 of jobs, what is relatively big number in comparison to other European countries.

\subsection{Challenges of automotive industry for its future global development}

Despite automotive industry is very progressive sector, it is under constant pressure. The need for continuous restructuring of production processes motivates companies to innovate. 
Businesses in this sector need to respond flexibly to turbulent environment and rapid global changes [5].

The industry is gradually transitioning from mechanical to software-based industry, or better said, from transportation focus to technological focus [6]. Drivers for change and technology development in the automotive industry are often linked to much wider issues that affect not only the automotive industry, but other activities and businesses. Among these issues include environmental concerns, safety, health, climate change, or resource availability [7].

Even before coronavirus outbreak, automotive industry was dealing with important global challenges. Current difficult situation caused by pandemic only multiplied the pressure on automotive sector and all subjects operating in it. The impact of COVID-19 on globally integrated automotive sector was significant. Problems with Chinese parts exports subsequently turned into manufacturing interruptions in Europe with potential long-term impact on automotive companies [8].

According to study of PWC (2020), the biggest factors for automotive industry are [9]:

- consumer demand (risk of consumer confidence loss with negative impact revenues and profits of automakers),

- capital issues (prioritising operational activities and thus limiting spends on R\&D on other projects or innovations),

- corporate strategy (decisions about manufacturing rationalization and possible exit from unprofitable markets),

- supply chains (liquidity problems of suppliers, disruption of global supply chains and complications for entire global automotive ecosystem),

- issues of retail companies (loss of demand may impact the structure of retail sector as companies will react to market changes).

Opazo-Basaez et al. outlined following key characteristics for the future of automotive industry [10]:

- qualified workforce,

- innovation,

- high level of complexity,

- standardization,

- reputation,

- modern technology,

- $\quad$ high quality product.

It means that operations and processes within the automotive industry are complex and based on the use of specialized technologies. The level of innovation in the industry is high and the standardization of processes and activities is essential [10].

The education and qualifications of the workers are also at a high level and the cooperation with universities and educational institutions is intensive. Within the automotive industry, the final products are perceived as high quality, companies emphasize on continuous employee training and whole sector tries to develop and apply processes leading to increased cost efficiency [11].

Before the crisis, new trends were rapidly emerging within automotive sector. The fact is, that current situation even intensified these changes and whole automotive ecosystem is forced to adapt. New technologies and innovation created ground for new directions of development, from which the main global trends in automotive industry are [6]:

- connected cars,

- autonomous cars,

- $\quad$ shared mobility,

- electromobility. 
The impact of these four trends is set to be even stronger in the future. The results of McKinsey (2009) study showed, that $80 \%$ of car producers worldwide plan to develop autonomous vehicles. The biggest players of car market already have wide portfolio of electromobiles or hybrid vehicles, and such development is expected to continue [12].

Boston Consulting Group in its study expects growing popularity of electromobiles while the share of cars with internal combustion engines will continue to decline. The study also expects that by 2030 , electric vehicles will account for $30 \%$ of all newly registered vehicles [13].

The European Alternative Fuel Observatory predicts a $100 \%$ share of zero-emission cars in the European Union by 2050. In 2025 the share of electric vehicles on all new cars in Europe is expected to reach $35 \%$ [14]. The automotive industry also offers the ground for innovation in terms of alternative fuels and alternative powertrains [15].

In the report of International Energy Agency we can find predictions about global expansion of electric vehicles. Specifically, it states that by the end of 2020, 50 million electric cars will be on the road globally. In 2040, this number is expected to be 280 million, what will represent $15 \%$ of the cars worldwide [6].

Automotive industry is currently undergoing significant changes and the ability of producers to innovate will be a key factor of their competitiveness. This dynamic period is influenced by already mentioned changes in industry (Industry 4.0), international measures of environmental protection, emission reduction efforts, and of course, COVID-19 restrictions. In the future, experts expect an even more intense application of IT elements and digitization into vehicles, what will result in growing diffusion of electric vehicles.

Another global challenge for the sector will be transformation in terms of the security, ownership model (towards a shared economy), or public transport. These trends bring risks but also opportunities for some countries. The study executed by OECD (2018) has found, that countries which possess education system of high quality while investing enough to research and development, have high innovation potential and technological innovation is an opportunity for their future development. On the contrary, technological innovation and automation significantly threaten automotive industry jobs - especially in countries where R\&D investments are low, what directly applies also for Slovakia.

Sustainability principles represent next challenge for the industry. Integrating more sustainability into business processes is becoming increasingly important for companies [16].

From environmental perspective, it is essential to minimize the use of non-renewable resources and ensure that they are handled responsibly. At the same time, the sustainable access to resources is crucial factor of global economic development - what applies even to automotive industry [17].

Automotive industry is a complex system of interconnected entities, products or processes, between which there is mutual interaction and economic benefits are generated. This sector has a significant impact on the environment, economy and public and thus plays important role in the issue of sustainable development. Whether it is finished product (car), or sub-product (automobile parts), all of them have to meet environmental standards supervised by specialized regulatory institutions [18].

\section{Conclusion}

In this paper we analysed the COVID-19 impact on automotive industry in Europe. Based on the data of relevant reports, we found that some countries were affected more than others, but overall impact on all European Union had serious negative consequences.

We also focused on the characteristics of global innovative trends that have become dominant for the future direction of the industry. Among those we can include especially 
development of electromobility and alternative drives, integration of Industry 4.0 elements into production processes or the growing pressure on the educational level of employees. Moreover, we cannot forget about the growing importance of green economy aspects, sustainability principles or digitization.

The impact of these trends can already be seen today and autnetromotive companies should be interested about them, if they want to be able to respond to these changes. The ability of companies to react, however, is associated with adequate amount of investments to research and development. In other words, companies are forced to innovate, if they want to be competitive. The high level of competition within the automotive industry will favor companies that adapt to rising importance of innovative trends and make optimal investments so that they can implement them in their production processes.

Even though automotive industry is facing strong headwinds, it cannot ignore the rise of global trends. For the industry it will be difficult to resume production activity to pre-crisis levels but new trends are also an opportunity for restart. Everything will depend on the pandemic situation development and on the measures of governments and institutions.

This paper is one of the partial outputs of the research grant no. I-20-103-00 entitled "Assessment of innovation potential in terms of new managerial trends on the base of proposed determinants within automotive industry", led by Ing. Monika Raková. PhD., University of Economics in Bratislava, Faculty of Business Management, Department of Business Economy.

\section{References}

1. Majtán, Š., Hojdík, V., Šlosár, R. (2017). Financial performance of automotive companies and its impact on concentration of automotive industry in Slovak republic. In P. Novak, Z. Jurigova, L. Kozubikova \& J. Zlamalova (Eds.), Finance and performance of firms in science, education and practice: proceedings of the 8th international scientific conference (pp. 617-627). Zlín: Tomas Bata University in Zlín.

2. Schulze, A., McDuffie, J.P., Täube, F.A. (2005). Introduction: Knowledge generation and innovation diffusion in the global automotive industry-Change and stability during turbulent times. Industry Corporation Changes 24 (3), 603-611.

3. ACEA. (2020). Automotive industry Pocket Guide 2020/2021.

4. Wang, L., Wells, P. (2020). Automobilities after SARS-CoV-2: A Socio-Technical Perspective. Sustainability 12(15), Art. No. 5978.

5. Vaz, C.R., Rauen, T.R.S., Lezana, A.G.R. (2017). Sustainability and Innovation in the Automotive Sector: A Structured Content Analysis. Sustainability 9(6), Art. No. 880.

6. IEA. (2017). Electric Vehicles Initiative (EVI). Retrieved from: https://www.iea.org/topics/ transport/evi/

7. Shaikh, A., Fernandes, A. (2016). Innovations in automotive industry and its influence on consumer behaviour. Tactful Management 4(12).

8. Delloite. (2020). Understanding the impact of COVID-19. Automotive sector.

9. PWC. (2018). Transforming vehicle production by 2030 \& How shared mobility and automation will revolutionize the auto industry. Retrieved from: https://www.strategyand.pwc.com/media/file/Transforming-vehicle-production.pdf

10. Opazo-Basaez, M., Vendrell-Herrero, F., Bustinza, O. (2018). Uncovering productivity gains of digital and green servitization: Implications from the automotive industry. Sustainability 10(5), Art. No. 1524.

11. Klewitz, J., Hansen, E.G. (2014). Sustainability-oriented innovation of SMEs: A Systematic Review. Journal of Cleaner Production 65, 57-75. 
12. McKinsey. (2019). McKinsey Center for Future Mobility: Race 2050 - a vision for the European automotive industry. Retrieved from: https://www.mckinsey.com/industries/automotive-and-assembly/our-insights/a-longterm-vision-for-the-european-automotive-industry

13. Boston Consulting Group. (2018). The Electric Car Tipping Point. The Future of Powertrains for Owned and Shared Mobility. Bcg.com. Retrieved from: https://www.bcg.com/ publications/2018/electric-car-tipping-point.aspx

14. EAFO, EU. (2020). Vehicles and fleet. Retrieved from: https://www.eafo.eu/countries/european-union/23640/vehicles-and-fleet

15. Zapata, C., Nieuwenhuis, P. (2010). Exploring innovation in the automotive industry: New technologies for cleaner cars. Journal of Cleaner Production 18, 14-20.

16. Beier, G., Kiefer, J., Knopf, J. (2020). Potentials of big data for corporate environmental management: A case study from the German automotive industry. Journal of Industrial Ecology 1, 1-14.

17. Merino-Saum, A., Baldi, A., Gunderson, O., Oberle, B. (2018). Articulating natural resources and sustainable development goals through green economy indicators: A systematic analysis. Resources, Conservation and Recycling 139, 90-103.

18. Abu-Rayash, A., Dincer, I. (2019). Sustainability assessment of energy systems: A novel integrated model. Journal of Cleaner Production, 212, 1098-1116. 